\section{Influence of Erosive and Abrasive Cycling on Bonding of Different Adhesive Systems Enamel: An In situ Study}

Marina Ciccone Giacomini ${ }^{1}$, Leslie Caroll Casas-Apayco ${ }^{2}$, Camila Moreira Machado $^{3}$, Maria Cristina Carvalho de Almendra Freitas ${ }^{4}$, Maria Teresa Atta ${ }^{1}$, Linda Wang'
'Department of Operative Dentistry, Endodontics and Dental Materials, Bauru Dental School, USP - Universidade de São Paulo, Bauru, SP, Brazil ${ }^{2} \mathrm{~S}$ chool of Dentistry, Universidad Peruana de Ciencias Aplicadas, Lima, Peru ${ }^{3}$ Department of Prosthodontics, Bauru Dental School, USP - Universidade de São Paulo, Bauru, SP, Brazil ${ }^{4}$ FACID-DeVry, - Faculdade integral Diferencial, Teresina, Pl, Brazil

Correspondence: Profa. Dra. Linda Wang, Alameda Octávio Pinheiro Brisolla, 9-75 17012-901, Bauru, SP, Brazil. Tel: +55-1432358323. email: wang.linda@ usp.br/wang.linda@uol.com.br

Key Words: dental enamel, dentin-bonding agents, tooth abrasion, tooth erosion

\section{Introduction}

The increased prevalence of erosion that affects dental hard tissues has stimulated the development of strategies and agents to prevent or control its effect (1). Erosion is primarily the result of the non-bacterial chemical attack usually involving acidic substances by intrinsic or extrinsic etiologies, which ultimately provokes the loss of dental hard tissue (2). In the beginning, it causes the softening of the surface (3) and its progression turns it more vulnerable to mechanical processes, and dental subsequent wear if not stopped (1-4)

In the consequence of an excessive or unusual increasing of the consumption of acidic beverages, erosive lesions have also been more evident $(1,5,6)$. As it is a multifactorial process, the compromising level of this event depends on the balance between chemical, behavioral and biological risk factors $(2,6)$.

In particular, dental erosion by orange juice has been the subject of numerous studies $(5,7)$. Its erosive potential is determined by several factors, including its $\mathrm{pH}$ and triattibility, chelating properties, and calcium, phosphate and fluoride concentration, frequency of exposure and duration of each episode of erosive exposure $(5,7)$.
De Carvalho Filho et al. (8) showed that the orange juice was able to significantly reduce $\mathrm{Ca}$ and $\mathrm{P}$ content of enamel, based on energy dispersive $\mathrm{X}$-ray spectrometry analysis. Studies have been pointed out that enamel demineralization can provoke structural damage with negative impact to bonding orthodontic brackets (7). Also, when eroded lesions present significant dental compromising, restorations of composite resin are commonly performed (9). With respect of this scenario, there is a lack of information if these alterations would be actually of concern in composition and structure of enamel in terms of erosive effects on interventions upon it $(2,10)$.

As toothbrushing represents the main oral abrasion process, its impact onto dental surface cannot be ignored. When associated with erosive conditions, both processes can act sinergically to modify enamel and dentin, intensifying their wear $(2,11)$.

Thus, the purpose of this study was to evaluate the enamel as bonding substrate after in situ / ex vivo erosive and/or abrasive cycling caused by industrialized orange juice, with the different categories of DBS. The null hypotheses tested were: 1 . There is no difference on bond strength to enamel according to DBS; 2 . There is no 
difference on BS to enamel after different challenges.

\section{Material and Methods}

\section{Ethical Aspects}

The Ethic Committee for Human Studies of Bauru School of Dentistry, University of São Paulo, Brazil approved this study (102/2009) before its beginning. Eight healthy volunteers received verbal and written information about the study and gave signed and witnessed consents to participate.

\section{Experimental Design}

This in situ/ ex vivo study involved the analysis of two factors: DBS, in three levels and erosive/abrasive challenge, in four levels. The response variable was the microtensile bond strength to enamel ( $\mu$ TBS).

\section{Enrolment of Participants}

All volunteers were selected according to inclusion criteria (12), who may present normal salivary flow rate $(\geq 1.0 \mathrm{~mL} / \mathrm{min})$. Neither active caries nor erosive lesions could be present. The saliva $\mathrm{pH}$ was assessed (mean $7.4 \pm 0.6$ ) as well. According to the medical history, neither acidic food consumption nor intrinsic acidic unbalanced condition was accepted to avoid confounding factors during the experiment. Also, it was instructed to the volunteers to not eat or drink any kind of food/ beverage, even water, when the appliance was in mouth. Thus, eight volunteers with appropriate general health, good dental health, known fluoride history, normal salivary function, and no medications that affect salivary function were enrolled.

\section{Specimen Preparation and Selection}

Bovine incisors were selected and stored in 0.1\% thymol solution at room temperature. From them, fragments $(4 \times 4 \times 2 \mathrm{~mm})$ were prepared using a digital low speed saw cut machine (Isomet 1000, Buehler, Lake Bluff, IL, USA) and two water-cooled diamond-impregnated disc (Diamond High Concentration. Wafering Blade-102 mm x $0.3 \times 12.7$ $\mathrm{mm} /$ Excet Corp., Enfield, CT, USA / Ref: 12205) with a stainless steel spacer $(7 \mathrm{~cm}$ diameter, $4 \mathrm{~mm}$ thick and 1.3 $\mathrm{cm}$ center hole). They were stored in plastic containers and covered with gauze soaked in deionized water at $4{ }^{\circ} \mathrm{C}$ temperature. Enamel surface was ground flat using 600 -grit and 1,200-grit SiC paper under running water (Politriz APL4, Arotec, Cotia, SP, Brazil). Between each polishing cycle, blocks were submitted to ultrasound cleaning (Ultrasonic Cleaner Mod. USC 750; Unique Ind. e Com. de Produtos Eletrônicos Ltda., São Paulo, SP, Brazil), for $2 \mathrm{~min}$. In the end, the enamel surfaces were polished with felt paper (Polishing Cloth Buheler, Lake Bluff, IL, USA 40-7618) and diamond suspension (Extec I Water based diamond permanent polishing suspension, Extec Corp., CT, USA, 1 micron 16.587). Superficial microhardness assessment aided to select one hundred ninety two standardized fragments (Knoop diamond, 25 g, 5s, HMV-2000; Shimadzu Corporation, Tokyo, Japan). Enamel blocks with a Knoop hardness number around $10 \% \pm$ of the media of total hardness (not less than $350 \mathrm{KHN}$ ) were selected.

\section{Intraoral/ Ex vivo and Extraoral Phases}

Specimens were sterilized in $2 \%$ formaldehyde solution $(\mathrm{pH}=7)$ at room temperature for 30 days (13). Each of the eight volunteers, worn their palatal devices containing 8 specimens, which were divided into four pairs as shown in Figure 1 and subjected to the challenges as described in Table 1. They were carried out extra orally in a single stage with the aid of a device made with Ethylene Vinyl Acetate (EVA) in accordance to Honorio et al. (14), to delimit the area that would be eroded or/and abraded. The experiment was conducted in three phases in a crossover design. In each phase, volunteers were randomized, in which the specimens would be restored with one of the three tested DBS. The composition of orange juice and used toothpaste are present in the Table 2.

After challenges, all blocks and appliances were then rinsed for $30 \mathrm{~s}$ with water supply prior to return them to the oral cavity. This cycle was followed for 5 days. For abrasive challenge an electric toothbrush (Cross action Power; Oral B, São Paulo, SP, Brazil) was used to standardize brushing with a slight pressure.

\section{Bonding Procedures}

For each group, specimens were randomized and restored with DBS: Adper Scotchbond MultiPurpose (3M

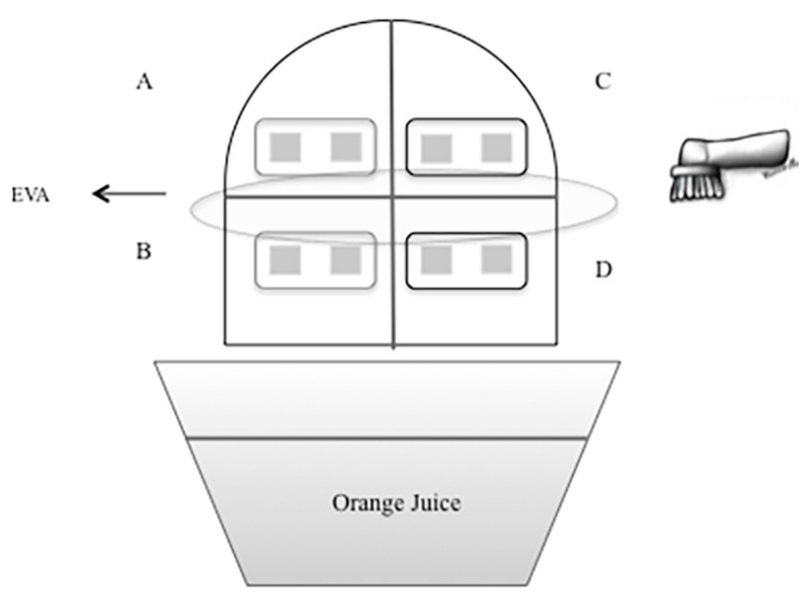

Figure 1. Representative schematic of palatal device and the tested challenge: $\mathrm{A}=\mathrm{CONT} ; \mathrm{B}=\mathrm{ERO} ; \mathrm{C}=\mathrm{ABR}$ and $\mathrm{D}=\mathrm{ERO}+\mathrm{ABR}$. Only $\mathrm{B}$ and $\mathrm{D}$ were immersed in orange juice. Each specimen was challenged 3x/day/5 min during 5 days. Only $\mathrm{C}$ and $\mathrm{D}$ were abraded after immersion in orange juice. 
ESPE, St. Paul, MN, USA) (three-step etch-and-rinse), Adper Single Bond 2 (3M ESPE) (two-step etch-and-rinse) and Clearfil SE Bond (Kuraray CO., LTD, Osaka, Japan) (two-step self-etching). For all DBS, acid-etching on enamel was made with 37\% phosphoric acid (Dentsply, Catanduva, $\mathrm{SP}$, Brazil) for 30s to MP and SB and for $20 \mathrm{~s}$ to $\mathrm{SE}$, as recommended by the manufacturers. Acid was removed by air-water spray for the same time of the etching step. All DBSs were applied according to the manufacturers, as described in Table 3, and light cured using a LED unit (Radii-cal- SDI, Bayswater, Victoria, Australia), with 1,000 $\mathrm{mW} / \mathrm{cm}^{2}$. Two increments of $2 \mathrm{~mm}$-layer of the composite Filtek $^{\mathrm{TM}}$ Z250 Universal Restorative ${ }^{\circledast}$ (3M ESPE, A2 shade) were inserted on enamel surfaces and light cured for 20 $s$ each. The specimens were then immersed in deionized water for $24 \mathrm{~h}$ at $37^{\circ} \mathrm{C}$.

\section{Microtensile Bond Strength Test}

Each block per group was longitudinally sectioned; perpendicularly to the bonding interface using an Isomet 1000 digital saw (Buehler, Lake Bluff, IL, USA). An average of 6 to 8 of $1 \mathrm{~mm}^{2}$-beams per block were obtained and measured using a digital caliper (Mitutoyo digital caliper, Mitutoyo America, Aurora, IL, USA). Each beam was fixed to the Bencor Multi-T testing apparatus (Danville Engineering Co., Danville, CA, USA) with cyanoacrylate resin (Super Bonder Flex Gel- Loctite, Henckel Ltda, Itapevi, SP, Brazil) and submitted to $\mu$ TBS in a universal testing machine (Emic, São José dos Pinhais, PR, Brazil) operating at a $0.5 \mathrm{~mm} /$ min crosshead speed and $50 \mathrm{~N}$ load cell. After testing, the

Table 1. Erosive/ abrasive challenges

\begin{tabular}{|c|c|c|}
\hline Groups* & Letters & Treatments \\
\hline Cont & A & Not challenged \\
\hline Ero & B & Specimens daily challenged for $3 \mathrm{x} /$ day $/ 5$ min with orange juice, during 5 days \\
\hline Abr & $\mathrm{C}$ & $\begin{array}{l}\text { Specimens daily brushed with dentifrice (Oral B Pró Saúde, Oral B, São Paulo, SP, Brazil) solution (1:3) fluoride (1,450 } \\
\text { ppm) and an electric toothbrush (Cross action Power / Oral B, São Paulo, SP, Brazil) for 3x/day/1 min, during } 5 \text { days }\end{array}$ \\
\hline Ero+Abr & $\mathrm{D}$ & $\begin{array}{l}\text { Specimens daily challenged for 3x/day/5 min with orange juice, followed by brushing with dentifrice } \\
\text { (Oral B Pró Saúde, Oral B, São Paulo, SP, Brazil) solution (1:3) fluoride }(1,450 \mathrm{ppm} \text { ) and electric } \\
\text { toothbrush (Cross action Power / Oral B, São Paulo, SP, Brazil) for 3x/day/1 min, during } 5 \text { days }\end{array}$ \\
\hline
\end{tabular}

* For each palatal appliance

Table 2. Composition of orange juice and fluoride toothpaste

\begin{tabular}{lcc}
\hline Product & Composition & $\mathrm{pH}$ \\
\hline $\begin{array}{l}\text { Fluoride Toothpaste (Oral B Pró Saúde, } \\
\text { Oral B, São Paulo, SP, Brazil) }\end{array}$ & $\begin{array}{c}\text { Sodium floride }(1,450 \mathrm{ppm}), \text { aqua, sorbitol, silica, sodium lauryl sulfate, cellulose gum, } \\
\text { stannous chloride, sodium gluconate, carrageenan, zinc citrate, titanium dioxide. }\end{array}$ \\
$\begin{array}{l}\text { Orange Juice (Suco Del Valle do Brasil, } \\
\text { Coca-Cola, Americana, SP, Brazil) }\end{array}$ & $\begin{array}{c}\text { Water, sugar, orange juice concentrate, natural flavor, } \\
\text { citric acid and antioxidant ascorbic acid. }\end{array}$ \\
\hline
\end{tabular}

Table 3. Protocol Application of each DBS

\begin{tabular}{|c|c|}
\hline Dentin Bonding Agent & Protocol Application \\
\hline $\begin{array}{l}\text { Adper Scotchbond } \\
\text { Multi Purpose (MP) }\end{array}$ & $\begin{array}{l}\text { 1. Acid etching for } 30 \mathrm{~s} ; 2 \text {. Wash for } 30 \mathrm{~s} ; 3 \text {. Dry with absorbent paper; } 4 \text {. Apply primer } \\
\text { and volatization with air dry for } 5 \mathrm{~s} ; 5 \text {. Apply Bond; } 6 \text {. Light-cure for } 20 \mathrm{~s}\end{array}$ \\
\hline $\begin{array}{l}\text { Adper Single } \\
\text { Bond } 2(\mathrm{SB})\end{array}$ & $\begin{array}{l}\text { 1. Acid etching for } 30 \mathrm{~s} ; 2 \text {. Wash for } 30 \mathrm{~s} ; 3 \text {. Dry with absorbent paper; } 4 \text {. Apply two consecutive } \\
\text { layers of bond and volatization with air dry for } 15 \mathrm{~s} \text {; } 5 \text {. Light-cure for } 10 \mathrm{~s}\end{array}$ \\
\hline Clearfil SE Bond (SE) & $\begin{array}{l}\text { 1. Acid etching for } 20 \mathrm{~s} ; 2 \text {. Wash for } 20 \mathrm{~s} ; 3 \text {. Dry with absorbent paper; } 4 \text {. Dry with } \\
\text { absorbent paper; } 5 \text {. Apply primer and wait for } 20 \mathrm{~s} ; 6 \text {. Volatilization with air dry; } 7 \text {. Apply } \\
\text { bond and create a uniform film using a gentle air stream; } 8 \text {. Light cure for } 10 \mathrm{~s}\end{array}$ \\
\hline
\end{tabular}


$\mu$ TBS was expressed in MPa as derived from dividing the maximum load ( $\mathrm{kgf}$ ) by the bond cross-sectional area $\left(\mathrm{cm}^{2}\right)$.

\section{Failure Mode Analysis}

After bonding tests, each fractured surface was analyzed with a handle digital microscope (DINO-LITEplus digital microscope, AnMo Electronics Corporation, Hsinchu-China) at 40x magnification and was categorized according to failure as: adhesive, mixed, cohesive in enamel or cohesive in resin failures.

\section{Statistical Analysis}

Data was calculated and statistically analyzed with Statistica software (Statsoft ${ }^{\oplus}$, Tulsa, OK, USA). The assumptions of normal distribution and of equality of variances were checked for all the variables using Kolmogorov-Smirnov and Levene test, respectively. As the assumptions were satisfied, data was analyzed by

two-way ANOVA and Tukey tests $(p<0.05)$. Scanning electronic microscopy (SEM) - Two additional specimens were prepared according to the same challenge protocols for SEM evaluation. These specimens were mounted in stubs, sputter coated with gold, and examined using a SEM (JSM T220A) at $\times 500$.

\section{Results}

Bond strength means and standard deviations are summarized in Table 4. Data revealed significance only for DBS $(p=0.006)$. There were no significant differences related nor to challenge neither to any interactions among these factors evaluated: challenge $(p=0.514), D B S$ $x$ challenge $(p=0.284)$. Also, when volunteer effect was evaluated, it was not significant either $(p=0.990)$ even when interacted with adhesive system $(p=0.157)$, challenge $(p=0.244)$ or with both the factors $(p=0.473)$.

Regarding the results in terms of DBS, SE was the DBS that even did not exhibit the greater values in all conditions overall, it did not differ to the other tested DBSs after any challenge. SB and MP statistically differed according to their performance in all situations.

Description of the distribution of failure modes is presented in Table 5 . Adhesive and mixed failure modes were predominant, which also state for a reliable test.

\section{Discussion}

Table 5. Failure mode distribution (\%) according to each challenge and dentin bonding system

\begin{tabular}{lccccc}
\hline $\begin{array}{l}\text { Adhesive } \\
\text { System }\end{array}$ & $\begin{array}{c}\text { Failure } \\
\text { Mode }\end{array}$ & Cont & Ero & Abr & Ero+Abr \\
\hline \multirow{2}{*}{ MP } & M & $47.37 \%$ & $47.00 \%$ & $67.00 \%$ & $57.14 \%$ \\
& A & $21.05 \%$ & $41.00 \%$ & $14.00 \%$ & $21.43 \%$ \\
& CE & $31.58 \%$ & $0.00 \%$ & $19.00 \%$ & $21.43 \%$ \\
& CR & $0.00 \%$ & $12.00 \%$ & $0.00 \%$ & $0.00 \%$ \\
SB & M & $57.89 \%$ & $42.00 \%$ & $53.00 \%$ & $37.50 \%$ \\
& A & $26.32 \%$ & $25.00 \%$ & $41.00 \%$ & $37.50 \%$ \\
& CE & $10.53 \%$ & $33.00 \%$ & $6.00 \%$ & $25.00 \%$ \\
& CR & $5.26 \%$ & $0.00 \%$ & $0.00 \%$ & $0.00 \%$ \\
& ME & $55.56 \%$ & $60.00 \%$ & $58.00 \%$ & $38.89 \%$ \\
& A & $27.78 \%$ & $30.00 \%$ & $21.00 \%$ & $27.78 \%$ \\
& CE & $16.67 \%$ & $10.00 \%$ & $21.00 \%$ & $33.33 \%$ \\
& CR & $0.00 \%$ & $0.00 \%$ & $0.00 \%$ & $0.00 \%$ \\
\hline
\end{tabular}

$\mathrm{A}=$ adhesive, $\mathrm{M}=$ mixed, $\mathrm{CE}=$ cohesive in enamel, $\mathrm{CR}=$ cohesive in resin . it was necessary to sterilize the specimens before their application. Based on the literature (13), the main concern is associated when formaldehyde is used to sterilize dentin as it can promote the chemical fixation of the collagen fibrils and alter their mechanical and biological properties. However, as enamel compound is mostly based on inorganic matrix (hydroxyapatite), there is no evidence of alterations using formaldehyde, in terms of bonding effect.

The results demonstrated significant differences in the adhesion according to DBSs, thus the first null hypothesis was rejected, as the bond strength was material-dependent. In the control group, Adper Single Bond 2 presented the highest means of bond strength to enamel, which showed no statistical difference to Clearfil SE Bond. However, it differed statistically to Adper Scotchbond Multipurpose, which presented the lowest means. When these results are compared to the other three challenged conditions, it is highlighted that Clearfil SE Bond was the unique DBS that was not affected in any situation.

For the etch-and-rinse DBSs (Adper Scotchbond
As this investigation was partially performed intraorally, 
Multipurpose/ three-step and Adper Single Bond 2/ two-step), previous studies displayed that etching with phosphoric acid permitted to remove bulk enamel in a range between 0.2 to $11.7 \mu \mathrm{m}$, depending on its concentration, form and time of etching (15). Based on the role of acid conditioning on enamel surface, a standard pattern of conditioning is expected as shown in Figure 2B. For all conditions, SB and MP varied from values of minimal to maximum BS in the comparison of the DBSs. Maybe it could be partially related to two main reasons: the variation of deep range after acid mineral removal of the surface and the composition of the two materials that interacted with the surface. It is relevant to emphasize that the etch-andrinse systems investigated in the present study, showed greater standard deviations compared to the self-etching system. Even these variations were observed, the data was homogeneous and also the volunteer effect was considered to discard any bias in the interpretation of them. Therefore it seems appropriate to suggest that the etch-and-rinse systems were more susceptible to interact to the altered surfaces. When the surfaces shown in the Figures $2 A, 3 A$, $4 A$ and $5 A$ are compared, differences on the challenged enamel allowed suggesting that these differences could exert these differences. Also, it is important to emphasize that as the surface was prepared, the aprismatic layer was removed during the polishing procedure before acid conditioning. Therefore, the most homogeneous layer was removed before.

Regarding the self-etching systems, as the Clearfil SE Bond system, an average of $0.5 \mu \mathrm{m}$ thickness of enamel is conditioned. Evidences revealed an unstable interface, which encouraged the previous use of phosphoric acid as etch-and-rinse systems (16). Through previous SEM observations, self-etching primer created a weaker etched pattern on the enamel surface than phosphoric acid. For this reason, it has been recommended the employment of phosphoric acid before its application as well (16), as was performed in the present study.

ClearfilSEBond system present 10-methacryloyloxydecyldihydrogen phosphate (MDP) as a relevant ingredient, a phosphate and bifunctional monomer that is able to bind chemically to dental substrate, which could explain the more stable $\mu$ TBS. MDP monomer form a nanolayer with the deposition of $\mathrm{Ca}$-MDP stable salt in the adhesive interface, thereby increasing the mechanical strength. On enamel surface, previous phosphoric acid is also recommended for Clearfil SE bond application and this DBS is able to bind to remainder $\mathrm{Ca}$ content.

Regarding the analysis of the bonding enamel surface, erosive and/or abrasive challenges showed no significant differences in adhesion, thus the second null hypothesis was accepted.

It is important to state that the used challenge protocols were based on the simulation of erosion used mainly in in vitro investigations, which showed its impact on the surface based on profilometric and hardness assessments $(4,17)$. However, its effect on bonding property and under in situ simulations was not discussed yet.

Based on the previous studies that evidenced structural compromising of enamel when subjected to erosive/ abrasive challenges (18), it was necessary to check if these alterations would damage on the establishment of a homogeneous resin-enamel interface somehow $(7,19)$. In this study, industrialized orange juice ( $\mathrm{pH} 3.1)$ was used to promote erosion. Barac et al. (20) demonstrated that erosion of the enamel surfaces exposed to orange juice was directly proportional to the exposure time. In the present study, we artificially reproduced erosive attack by 5 -min
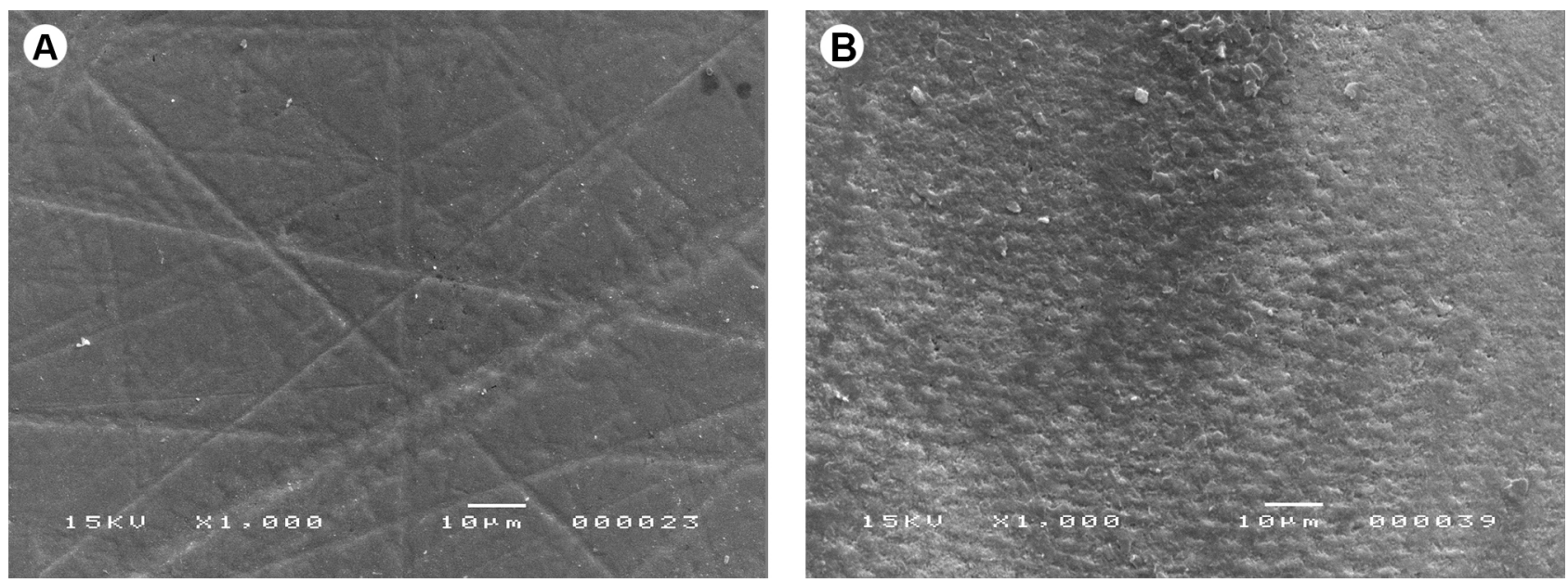

Figure 2. A: Surface of control polished bovine enamel. Some scratches resulted from the polishing procedure are observed. B: Surface of control group after etching with phosphoric acid gel. The standard pattern of prisms exposures is observed, presenting surface irregularities. 

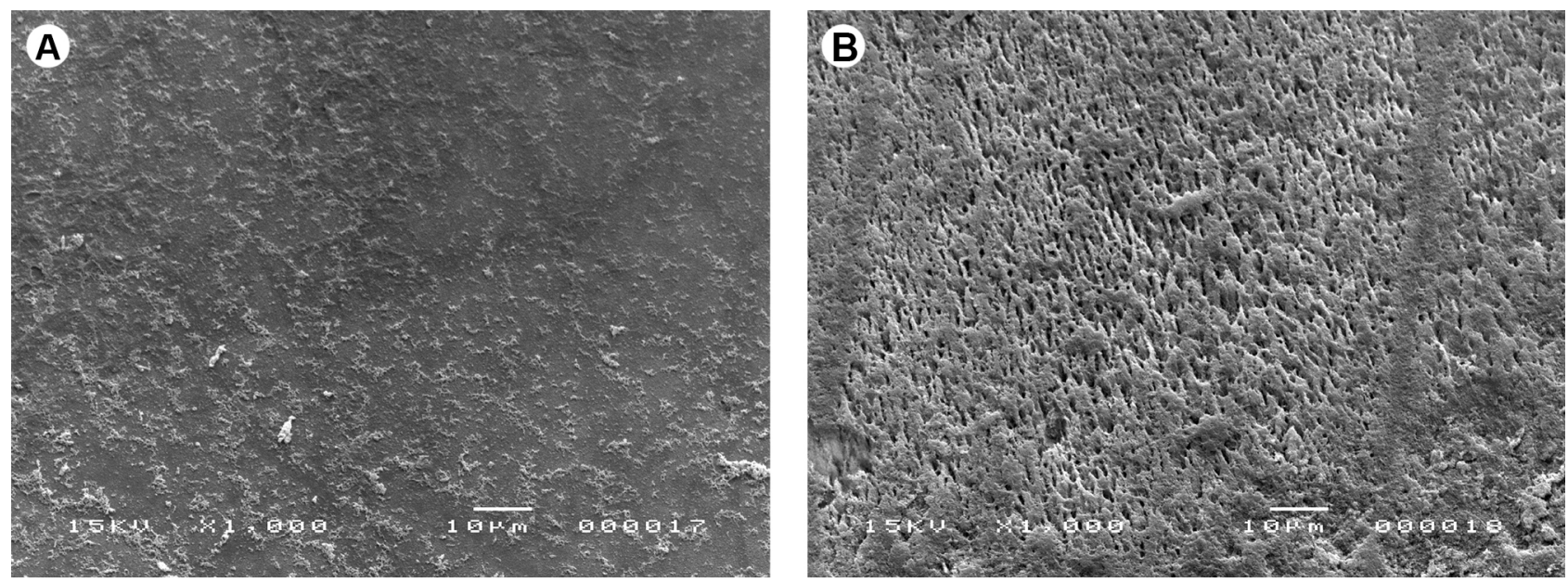

Figure 3. A: Surface of eroded bovine enamel. Evidence of demineralization of the surface, with presence of irregularities promoted by the erosive challenge. B: Surface of eroded bovine enamel after etching with phosphoric acid gel. The standard pattern of prisms exposures is observed more intensive compared to not challenged condition.
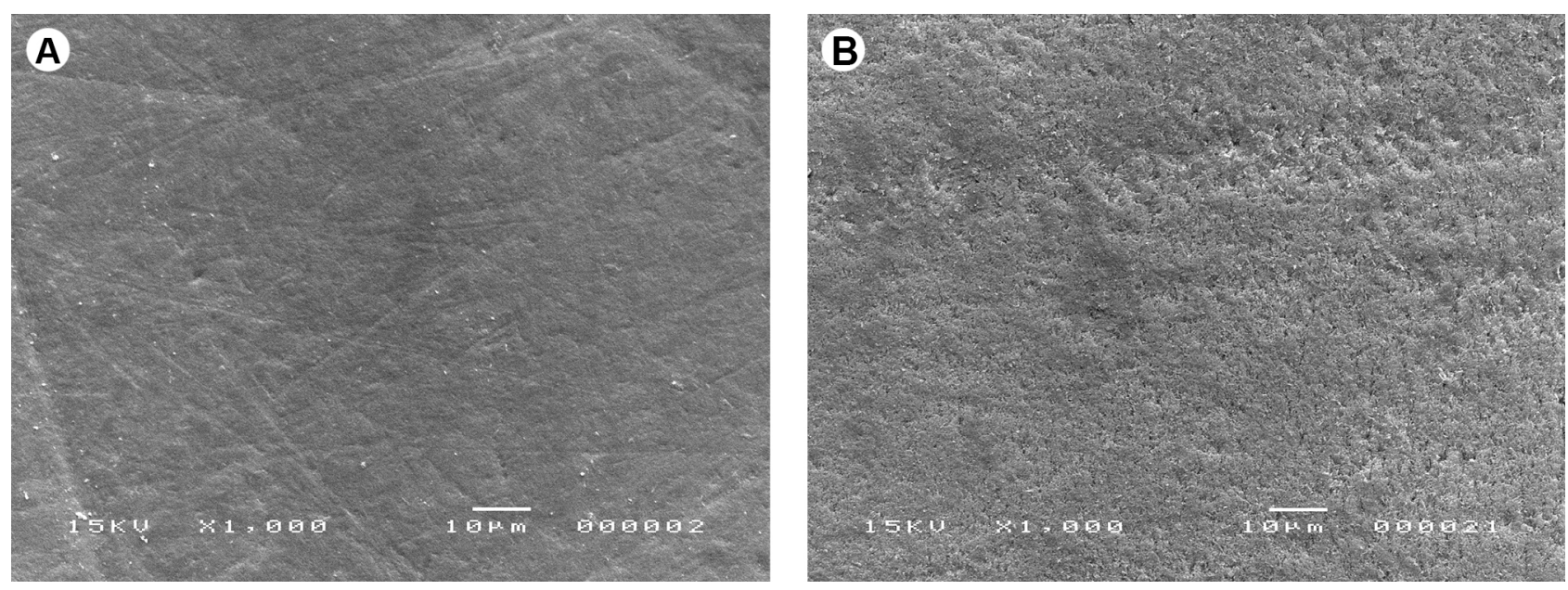

Figure 4. A: Surface of abraded bovine enamel. Discrete scratches are observed on the surface, specially compared to control group. B: Surface of abraded bovine enamel group after etching with phosphoric acid gel. The surface irregularities were more discrete.
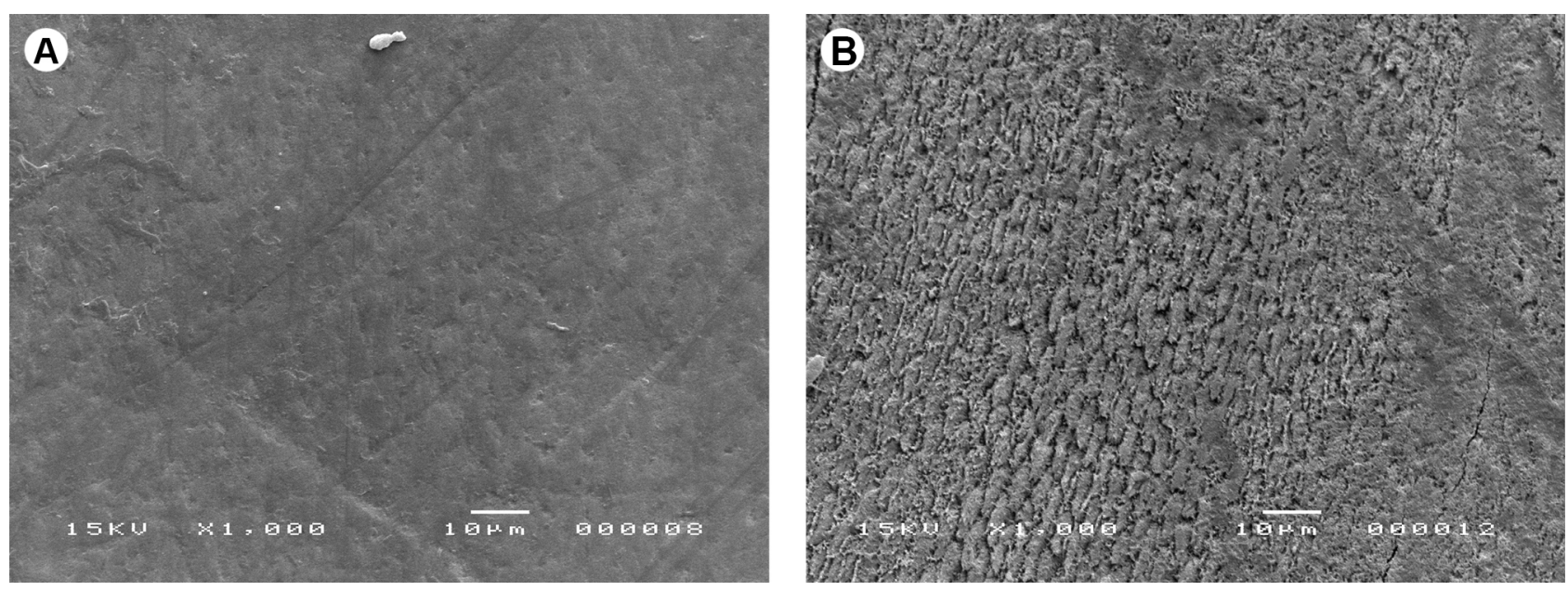

Figure 5. A: Surface of eroded/abraded bovine enamel. Discrete demineralization on the surface is observed. B: Surface of eroded/abraded bovine enamel after etching with phosphoric acid gel. More intense irregularities were shown. 
immersion in orange juice. Based on the comprehension of the mechanism of erosion in two distinct phases, softening and wear (2), it seems reasonable to expect that phosphoric acid gel, with $\mathrm{pH}$ around 0.5 , creates microporosities deeper than that provoked by orange juice, and thus, it is able to standardize the surface and be enough to favor for the penetration of the dentin bonding systems.

Usually it is expected for a simple and safe bonding to enamel, in which the adhesive resins penetrate into acid-etched enamel prisms and envelop apatite crystallites (16). Figure $2 A$, shows a representative aspect of sound enamel. After etching with phosphoric acid gel (Fig. 2B) prisms exposures are observed. These figures represent the expected standard situation. When enamel is somehow altered, changes in this substrate might affect the bond strength, failure mode, and the tag formation (16). Enamel solubility, in part, depends on the individual biologic variation in their structural arrangement and composition $(4,13)$. However, some other factors also may be considered, as the enamel response to the frequent oral challenges and fluoride exposition for instance (21). As erosion attacks mineral content of enamel by removing them, this variation may determine varied alterations (17). The superficial softened layer can vary on a range of $20 \mu \mathrm{m}$, which is considered a fragile surface and should represent a poorly mineralized layer with no loss of substance (17). Eroded surface (Fig. 3A), has a different pattern compared to the sound enamel, with signs of demineralization and presence of irregularities on surface. However, when eroded enamel was etching with phosphoric acid gel (Fig. 3B) a more intense pattern of prisms exposures compared to not challenged condition (control or abraded) is observed. Abraded enamel (Fig. 4A) shows a slight increase of scratches, even so close to the sound enamel, as expect for this situation. When eroded/ abraded surfaces was analyzed (Fig. 5A) a discrete demineralization on the surface is observed and after etching (Fig. 5B), more intense irregularities were shown. The surface after challenge and after acid etching is closer to the noticed for eroded specimens in both conditions, respectively, suggesting that the erosion protocol may exert a potential alteration in this substrate, even it is not evidenced under bonding tests.

With increasing erosion episodes, substance loss by far exceeds subsurface mineral loss. However, clinically it is not possible to assure if the substrate is actually softened by the mineral loss only or if wear already occurred. Therefore, the bonding procedure can be performed on an altered substrate. In this study, dental erosion was simulated with orange juice, seeing that this beverage is considered one of the most aggressive in the erosive potential. The intention was to provoke a situation consistent with what occurs clinically (22).
Thus, all the tested systems probably reached similar pattern of etching as all of them were previously treated with phosphoric acid before adhesive application. Etched enamel surface provides increasing of available area for adhesion, through providing microporosities which facilitates penetration of adhesive, promoting a mechanically adhesion of resin polymerized to enamel (23). Cruz et al. (24) found that there is no difference in bonding effectiveness in eroded bovine enamel among adhesive systems Adper Single Bond 2 and Clearfil SE Bond, when phosphoric acid was used, which is in accordance to the results from the present study.

Taking it into account, it was expected that eroded or abraded enamel result in a more irregular substrate, which in turn could be advantageous to bonding as these substrates increase the area for wettability and penetration of these systems (19). Probably, this may not exert any impact, probably due to the in situ protocol. Saliva seems to play an important role in minimizing enamel wear in erosive/abrasive attack. The buffering capacity, calcium and phosphate contents of saliva and the acquired pellicle may counteract the erosive attacks, by reducing enamel loss and softening, enhancing its rehardening and minimizing the surface wear by subsequent tooth-brushing procedures (11).

Additionally, when investigations are carried out using in situ models, a closer situation to actual oral environment is allowed, with the presence of saliva and formation of an acquired pellicle $(5,22)$. Saliva may minimize the impact of theses challenges as well due to its properties of buffering capacity and ability do neutralize acidic products $(3,12-14)$. Even previous studies evidenced actual changes on enamel surface; the preconditioning with phosphoric acid would be enough to promote a reactive surface for bonding process, without the indication of roughening and allowing a more conservative approach (22).

The results of this experiment contribute to support that no additional treatment may be required before bonding to eroded/abraded enamel surfaces. Even previous studies evidenced actual changes on enamel surface; the preconditioning with phosphoric acid would be enough to promote a reactive surface for bonding process, without the indication of roughening and allowing a more conservative approach.

\section{Resumo}

Este estudo avaliou o impacto de suco de laranja na resistência de união $(R U)$ de sistemas adesivos dentinários (SAD) à superfície do esmalte após a simulação com uma ciclagem erosiva in situ/ex vivo. Cento e noventa e dois fragmentos de esmalte bovino $(4 \times 4 \times 2 \mathrm{~mm})$ foram obtidos e randomizados considerando a microdureza superficial, e distribuídos em dispositivos palatinos para 8 voluntários, em três fases (uma para cada SAD), contendo 8 blocos, os quais foram alocados em 4 pares. Diariamente, esses pares eram submetidos às seguintes condições extraoralmente: CONT- sem desafio erosivo ou abrasivo; ERO- desafio erosivo somente; 
ABR- desafio abrasivo somente; e ERO+ABR- com desafio erosivo e abrasivo. A ciclagem erosiva (imersão em suco de laranja, 3 vezes/dia/5 $\mathrm{min} / 5$ dias) e/ou ciclagem abrasiva (escova dentária elétrica, 3 vezes/dia/1 $\mathrm{min} / 5$ dias) foram feitas. Após estas ciclagens, todos os espécimes foram restaurados com os sistemas adesivos Adper Scotchbond Multi Purpose (MP), Adper Single Bond 2 (SB) ou Clearfil SE Bond (SE), e com a resina composta Filtek Z250. Após 7 dias, palitos (área $\approx 1 \mathrm{~mm}$ ) eram obtidos e submetidos ao teste de resistência de união por microtração $(\mu \mathrm{TBS})$ a 0,5 $\mathrm{mm} / \mathrm{min}$. Os dados foram estatisticamente analisados por ANOVA e teste de Tukey $(\alpha=0,05)$. Os modos de fratura foram determinados utilizando um microscópio digital (40x). SAD foi o único fator estatisticamente significante. SE foi o único $S A D$ não afetado por qualquer desafio, enquanto o MP e o SB apresentaram um desempenho de acordo com o cenário. As fraturas do tipo mista e adesiva foram predominantes em todos os grupos. 0 desempenho geral sugeriu que RU ao esmalte após desafio erosivo/ abrasivo por suco de laranja não foi afetada e foi material-dependente.

\section{Acknowledgements}

This study was supported by Foundation for Research Support of the State of São Paulo (FAPESP) (grant 2010/01442). Authors are also greatful for Oral B for material donation.

\section{References}

1. Aidi HE, Bronkhorst EM, Huysmans MC, Truin GJ. Factors associated with the incidence of erosive wear in upper incisors and lower first molars: a multifactorial approach. J Dent 2011;39:558-563.

2. Huysmans MC, Chew HP, Ellwood RP. Clinical studies of dental erosion and erosive wear. Caries Res 2011;45:60-8.

3. Shellis RP, Ganss C, Ren Y, Zero DT, Lussi A. Methodology and models in erosion research: discussion and conclusions. Caries Res 2011;45:69-77.

4. Torres CP. Surface and subsurface erosion of primary enamel by acid beverages over time. Braz Oral Res 2010;21:337-345.

5. Scaramucci T, Sobral MA, Eckert GJ, Zero DT, Hara AT. In situ evaluation of the erosive potential of orange juice modified by food additives. Caries Res 2012;46:55-61.

6. Zero DT, Lussi A. Erosion - chemical and biological factors of importance to the dental practitioner. Int Dent J 2005;55:285-290.

7. Oncag G, Tuncer AV, Tosun YS. Acidic soft drinks effects on the shear bond strength of orthodontic brackets and a scanning electron microscopy evaluation of the enamel. Angle Orthod 2005;75:247-253.

8. Carvalho Filho AC, Sanches RP, Martin AA, Espirito Santo AM, Soares LE. Energy dispersive $X$-ray spectrometry study of the protective effects of fluoride varnish and gel on enamel erosion. Miscroc Research Tech 2011;74:839-844.

9. Jaeggi $\mathrm{T}$, Gruninger A, Lussi A. Restorative therapy of erosion. Monogr Oral Sci 2006;20:200-214.

10. Ionta $\mathrm{FQ}$, Boteon $\mathrm{AP}$, Moretto $\mathrm{MJ}$, Júnior $\mathrm{OB}$, Honório $\mathrm{HM}$, Silva $\mathrm{TC}$, et al.. Penetration of resin-based materials into initial erosion lesion: $\mathrm{A}$ confocal microscopic study. Microsc Res Tech 2016;79:72-80.

11. Rios D, Honório HM, Magalhães AC, Delbem ACB, Machado MAAM, Silva SMB et al.. Effect of salivary stimulation on erosion of human and bovine enamel subjected or nor to subsequent abrasion: An in situlex vivo study. Caries Res 2006;40:218-223.

12. Featherstone, JDB, Zero DT. An in situ model for simultaneous assessment of inhibition of demineralization and enhancement of remineralization. J Dent Res 1992;71:804-810.

13. Rios $D$, Santos $F C$, Honório HM. Magalhães $A C$, Wang $L$, de Andrade Moreira Machado MA et al.. An in situlex vivo comparison of the ability of regular and light colas to induce enamel wear when erosion is combined with abrasion. Quintessence Int 2001;42:44-50.

14. Honório $H M$, Rios $D$, Santos $C F$, Magalhães $A C$, Buzalaf $M A$, Machado MA. Effects of erosive, cariogenic or combined erosive/cariogenic challenges on human enamel: an in situlex vivo study. Caries Res 2008:42:454-459.

15. Gwinnett AJ. Histologic changes in human enamel following treatment with acidic adhesive conditioning agents. Arch Oral Biol 1971;16:731738.

16. Pashley DH, Tay FR, Breschi L, Tjäderhane L, Carvalho RM, Carrilho M, et al.. State of the art etch-and-rinse adhesives. Dent Mater 2011;27:1-16.

17. Ganss C, Lussi A, Klimek J. Comparison of calcium/phosphorus analysis, longitudinal microradiography and profilometry for the quantitative assessment of erosive demineralisation. Caries Res 2005;39:178-184.

18. Schlueter N, Hara A, Shellis RP, Ganss C. Methods for the measurement and characterization of erosion in enamel and dentine. Caries Res 2011;45:13-23.

19. Marshall SJ, Bayne SC, Baier R, Tomsia AP, Marshall GW. A review of adhesion science. Dent Mater 2010;26:11-16.

20. Barac R, Gasic J, Trutic N, Sunaric S, Popovic J, Djekic P et al. Erosive effect of different soft drinks on enamel surface in vitro: application of stylus profilometry. Med Princ Pract 2015;24:451-457.

21. Torii $Y$, Itou K, Nishitani Y, Ishikawa K, Suzuki K. Effect of phosphoric acid etching prior to self-etching primer application on adhesion of resin composite to enamel and dentin. Am J Dent 2002;15:305-308.

22. Wang L, Casas-Apayco LC, Hipólito AC, Dreibi VM, Giacomini MC, Bim Junior 0, et al.. Effect of simulated intraoral erosion and/or abrasion effects on etch-and-rinse bonding to enamel. Am J Dent 2014;27:2934.

23. Retief DH. Adhesive techniques sufficient to prevent microleakage. Oper. Dent 1987;12:140-145.

24. Cruz JB, Bonini G, Lenzi TL, Imparato JC, Raggio DP. Bonding stability of adhesive systems to eroded dentin. Braz Oral Res 2015;29:1-6.

Received June 28, 2016

Accepted August 4, 2016 